\title{
RANCANG BANGUN TATA RUANG PERPUSTAKAAN SEBAGAI PUSAT \\ SUMBER BELAJAR DI PONDOK PESANTREN RIYADUL FALAH KABUPATEN TASIKMALAYA PROVINSI JAWA BARAT
}

\author{
Yunus Winoto* \\ Rinrin Mahani Rustikasari**
}

\begin{abstract}
This research aims to designing of spatial design library as learning resources centers in boarding Riyadul Falah. The scope of this research is on optimal spatial aspects is aspect of functional, aspect of psychological, aspect of aesthetics, and aspect of security materials library. The research method used was action research. Technique data collection done by observation, interview, and study of the library. While the data collection techniques to determine the response of users using questionnaires. The research results showed that design of library as learning resources centers already appropriate With needs and expectation of the Islamic boarding schools. And is in accordance with the concept of spatial design library with attention to the four aspects of them, aspect of functional, aspect of psychological, aspect of aesthetics, and aspect of security material library. Feedback from user after result action research of produce objective a many visit in library and lending in library. Librarian is happy with the spatial design of library.
\end{abstract}

Keywords: Spatial Library, Spatial aspects of the library. Learning Resources Center, school library

\section{Pendahuluan}

Dalam sistem pendidikan modern keberadaan perpustakaan merupakan bagian yang tidak bisa dipisahkan dari lembaga pendidikan dimana perpustakaan tersebut berada. Melalui

\footnotetext{
* Staf pengajar Pada Program Studi Perpustakaan dan Sains Informasi FIKOM UNPAD.

**Pustakawan pada perpustakaan sekolah Yayasan Pondok Pesantren Riyadul Falah Tasikmalaya
} 
perpustakaan para peserta didik maupun para guru dapat memanfaatkan dan mengakses berbagai sumber informasi untuk menunjang proses belajar mengajar. Apalagi jika dikaitkan dengan salah satu upaya pemerintah untuk membangun budaya literasi masyarakat sebagai prasyarat untuk menghasilkan peserta didik yang memiliki keterampilan abad 21 yakni keterampilan berpikir kritis (critical thingking dan problem solving), kolaboratif (colaboratif), kreatif (creative and inovative) serta keterampilan dalam berkomunikasi (communicative).

Menyoal tentang budaya literasi di Indonesia, memang diakui masih jauh ketinggalan jika dibandingkan dengan perkembangan budaya literasi di beberapa negara maju. Apabila di beberapa negara maju sudah masuk pada era literasi baru fase fase 1 bahkan ada yang mulai masuk era literasi baru fase 2, di negara kita pembicaraan literasi masih sekitar penguasaan enam literasi dasar yakni literasi baca tulis, literasi numerasi, literasi sains, literasi digital, literasi finansial serta literasi budaya dan kewarganegaraan. Adapun penguasaan enam literasi dasar ini telah menjadi kesepakatan seluruh peserta forum ekonomi dunia yang dilakukan pada tahun 2015. Penguasaan literasi dasar harus menjadi kompetensi yang harus dimiliki setiap anggota masyarakat. Oleh karena demikian program ini dilakukan secara terintegrasi baik di lingkungan masyarakat, sekolah maupun lingkungan keluarga melalui sebuah gerakan yang dikenal dengan gerakan literasi nasional (GSN). Selain itu juga indikator lain masih rendahnya budaya litarsi di negara kita paling tidak ditunjukkan oleh beberapa hasil kajian yang telah dilakukan beberapa lembaga riset, misalnya Programme for International Student Assesment (PISA) menyebutkan literasi masyarakat Indonesia pada tahun 2015 menjadi negara yang menduduki peringkat 64 dari 70 negara serta Indonesia National Assesment Program (INAP) menyatakan nilai kemampuan membaca masyarakat kita hanya sekitar $46,84 \%{ }^{1}$

Sebagaimana yang telah dikemukakan di atas dalam mengembangkan budaya literasi harus dilakukan secara terintegrasi

1 Rohanda dan Winoto, Yunus. Studi Tentang Pemetaan Budaya Literasi Masyarakat dan Pengembangan Model Indeks Membaca Masyarakat Di KBB. (Hasil Penelitian), (Bandung : FIKOM UNPAD, 2017). 
baik di lingkungan masyarakat, lingkungan keluarga maupun lingkungan sekolah. Berkaitan dengan peran sekolah maupun lembaga pendidikan lainnya dalam mendukung program gerakan literasi diperlukan sebuah sarana atau fasilitas yang menyediakan berbagai sumber informasi. Adapun sarana yang dimaksudkan adalah perpustakaan.

Berbicara tentang perpustakaan, khususnya perpustakaan sekolah Sulistyo Basuki ${ }^{2}$ menyatakan bahwa Perpustakaan sekolah adalah perpustakaan yang tergabung pada sebuah sekolah, dikelola sepenuhnya oleh sekolah yang bersangkutan, dengan tujuan utama membantu sekolah untuk mencapai tujuan khusus sekolah dan tujuan khusus pendidikan pada umumnya. Dari pengertian tersebut bahwa keberadaan perpustakaan sekolah dapat membantu sekolah untuk mencapai tujuan pembelajaran, dan dapat memenuhi kebutuhan informasi siswa di sekolah.

Masih tentang perpustakaan sekolah jika merujuk pada Undang-Undang Nomor 2 Tahun 1989 pasal 35 tentang Sistem Pendidikan Nasional $^{3}$ menyatakan bahwa Perpustakaan sekolah disebut sebagai pusat sumber belajar dimana setiap satuan pendidikan jalur pendidikan sekolah, baik yang diselenggarakan oleh pemerintah maupun oleh masyarakat, harus menyediakan sumbersumber belajar. Perpustakaan merupakan salah satu sumber belajar yang ada di lingkungan sekolah. Perpustakaan sebagai sumber belajar adalah berbagai sumber baik itu berupa data, orang atau wujud tertentu yang dapat digunakan oleh siswa dalam belajar baik yang digunakan secara terpisah maupun secara terkombinasi sehingga mempermudah siswa mencapai tujuan belajarnya.

Sebagai bagian integral dari sebuah proses pembelajaran perpustakaan memiliki beberapa fungsi yang salah salah satunya adalah sebagai pusat sumber belajar dalam rangka mendukung tercapainya tujuan pendidikan yang diselenggarakan disekolah atau madrasah. Berkaitan dengan pentingnya keberadaan perpustakaan di setiap sekolah atau lembaga pendidikan lainnya dengan tegas tertuang dalam Peraturan Pemerintah Nomor 19 Tahun 2005 tentang

2 Sulistyo-Basuki. Pengantar ilmu Perpustakaan, (Jakarta :Gramedia Pustaka Utama, 1991).

${ }^{3}$ Undang-undang No 2 tahun 1989 Tentang Sistem Pendidikan Nasional, Pasal 35. 
Standar Nasional Pendidikan pada Bab VII pasal 42 yang menyebutkan bahwa ${ }^{4}$ :

1) Setiap satuan pendidikan wajib memiliki sarana yang meliputi perabot, peralatan pendidikan, media pendidikan, buku dan sumber belajar lainnya, bahan habis pakai, serta perlengkapan lain yang diperlukan untuk menunjang proses pembelajaran yang teratur dan berkelanjutan.

2) Setiap satuan pendidikan wajib memiliki prasarana yang meliputi lahan, ruang kelas, ruang pimpinan satuan pendidikan, ruang pendidik, ruang tata usaha, ruang perpustakaan, ruang laboratorium, ruang bengkel kerja, ruang unit produksi, ruang kantin, instalasi jasa dan daya, tempat berolahraga, tempat beribadah, tempat bermain, tempat berkreasi, dan ruang/tempat lain yang diperlukan untuk menunjang proses pembelajaran yang teratur dan berkelanjutan.

3) Dengan demikian Peraturan di atas menguatkan bahwa sekolah atau lembaga pendidikan wajib memiliki perpustakaan.

Apabila memperhatikan ketentuan peraturan pemerintah tersebut di atas semakin menegaskan bahwa perpustakaan merupakan bagian yang tidak dipisahkan dari sebuah lembaga pendidikan baik sekolah maupun madrasah. Sedangkan hal yang berkaitan dengan standar, koleksi maupun layanan yang harus disediakan suatu perpustakaan, dalam Peraturan Pemerintah Nomor 19 tahun 2015 khususnya pada Bab VII bagian ketiga pasal 23 ayat 1 sampai dengan 4 yang berisi sebagai berikut ${ }^{5}$ :

1) Setiap sekolah/madrasah menyelenggarakan perpustakaan yang memenuhi standar nasional perpustakaan dengan memperhatikan Standar Nasional Pendidikan.

2) Perpustakaan sebagaimana dimaksud pada ayat (1) wajib memiliki koleksi buku teks pelajaran yang ditetapkan sebagai buku teks wajib pada satuan pendidikan yang bersangkutan

4 Peraturan Pemerintah No. 19 Tahun 2005, tentang Standar Nasional Pendidikan.

${ }^{5}$ Ibid, Bab VII pasal 23, ayat 1-4. 
dalam jumlah yang mencukupi untuk melayani semua peserta didik dan pendidik.

3) Perpustakaan sebagaimana dimaksud pada ayat (1) mengembangkan koleksi lain yang mendukung pelaksanaan kurikulum pendidikan.

4) Perpustakaan sekolah/madrasah melayani peserta didik pendidikan kesetaraan yang dilaksanakan di lingkungan satuan pendidikan yang bersangkutan.

Dalam penyelenggaraan perpustakaan sekolah atau madrasah supaya bisa berjalan secara optimal, selain perlu dikelola oleh tenaga atau orang yang memiliki kompetensi yang sesuai dengan bidangnya juga perlu dilengkapi sarana dan prasarana yang memadai sesuai dengan standar penyelenggaraan perpustakaan sekolah. Salah satu hal yang kerapkali menjadi permasalahan dalam penyeleng-garaan perpustakaan sekolah maupun madrasah adalah yang menyangkut ruangan dan penataannya. Hal ini juga seperti yang terlihat dalam penyelenggaraan perpustakaan yang ada di Pondok Pesantren Riyadul Falah Tasikmalaya. Berdasarkan observasi awal yang kami lakukan di lokasi penelitian ini di Pesantren Riyadul Falah perlu memiliki ruang khusus perpustakaan yang dapat menampung semua buku yang dimilikinya dan membantu santri dalam memenuhi kebutuhan informasi. Sehingga dengan adanya ruangan khusus untuk perpustakaan buku-buku akan tertata secara rapi dan dapat membantu dalam proses pencarian. Oleh karena itu yang harus diutamakan adalah penataan ruang seperti penempatan rak buku, penataan untuk koleksi pustaka, dan tempat untuk membaca. Penataan ruangan perpustakaan perlu dilakukan secara hati-hati dan mempertimbangkan berbagai aspek.

Mengenai penataan ruangan perpustakaan Darmono ${ }^{6}$ menyebutkan bahwa terdapat empat (4) aspek penataan ruang perpustakaan yang optimal, adapun aspek-aspek tersebut antara lain: aspek fungsional, aspek psikologi pengguna, aspek estetika, dan aspek keamanan bahan pustaka.

Berdasarkan latar belakang masalah tersebut di atas, maka dapat dirumuskan masalah sebagai berikut : "Bagaimana rancang

6 Darmono. Perpustakaan sekolah : pendekatan manajemen dan tata kerja (Jakarta : Grasindo, ) 234 
bangun tata ruang perpustakaan sebagai pusat sumber belajar di Pesantren Riyadul Falah?". Sedangkan tujuan dari penelitian ini adalah sebagai berikut :

1) Untuk mengkaji rancang bangun tata ruang perpustakaan pesantren Riyadul Falah berdasarkan aspek fungsional.

2) Untuk mengkaji rancang bangun tata ruang perpustakaan pesantren Riyadul Falah berdasarkan aspek psikologi pengguna.

3) Untuk mengkaji rancang bangun tata ruang perpustakaan pesantren Riyadul Falah berdasarkan aspek estetika.

4) Untuk mengkaji rancang bangun tata ruang perpustakaan pesantren Riyadul Falah berdasarkan aspek keamanan bahan pustaka.

\section{Metode Penelitian}

Dalam penelitian ini metode yang digunakan adalah penelitian tindakan (action research). Mengenai penelitian tindakan menurut Kemmis dan Mc Taggart sebagaimana yang dikuti Nurul Zuriah ${ }^{7}$ menyebutkab bahwa penelitian tindakan merupakan upaya mengujicobakan ide-ide ke dalam praktik untuk memperbaiki atau mengubah sesuatu agar memperoleh dampak nyata dari situasi selanjutnya. Penelitian tindakan, mengkaji persoalan yang muncul dari dalam masyarakat dan berupaya memecahkan permasalah yang ada di lapangan. Kemudian membuat produk untuk dapat di terapkan di masyarakat dan dapat melakukan perubahan terhadap permasalahan tersebut. Adapun mengenai model penelitian tindakan dapat digambarkan sebagai berikut :

\footnotetext{
${ }^{7}$ Nurul Zuriah. Penelitian Tindakan : dalam bidang pendidikan dan social, (Malang : Bayu Media Publishing), 54
} 


\section{Gambar 1 : Model Penelitian Tindakan}

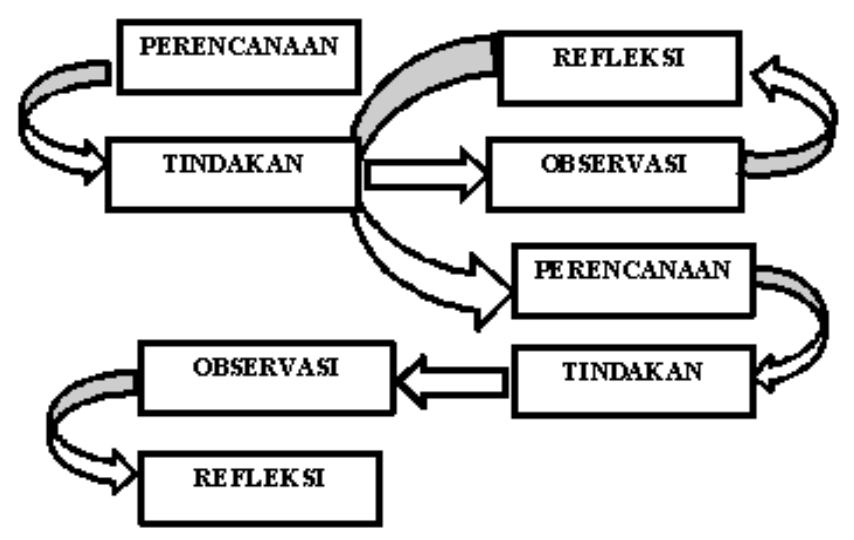

Sebelum melakukan perencanaan, peneliti melakukan kegiatan Pra penelitian. Kegiatan pra penelitian ini diawali dengan wawancara tidak terstuktur kepada guru dan siswa yang nantinya akan menentukan tindakan yang mengarah kepada perbaikan. Pra penelilitian ini merupakan hasil dari observasi, wawancara di lapangan. Kegiatan pra penelitian ini mengajukan beberapa pertanyaan mengenai kondisi tentang keberadaan perpustakaan. apakah sudah adanya penataan ruang perpustakaan yang nyaman bagi pengguna. Setelah melakukan pra penelitian peneliti bersama guru dan siswa melakukan diskusi apa yang diharapkan mereka.

Ada beberapa tahapan yang dilakukan dalam kegiatan penelitian ini yaitu tahap penyusunan rencana, tahap pelaksanaan, tahap observasi serta refleksi yakni peneliti melakukan evaluasi terhadap apa yang telah dilakukan. Adapun mengenai subjek dalam penelitian ini adalah pimpinan pesantren, guru, serta beberapa siswa yang ada di Pesantren Riyadul Falah. Sedangkan objek dalam penelitian ini yaitu rancang bangun tata ruang perpustakaan yang meliputi empat (4) aspek yakni aspek fungsional, aspek psikologi pengguna, aspek estetika, serta aspek keamanan bahan pustaka.

Kemudian sumber data dalam penelitian terdiri dari sumber data primer yakni data yang dikumkumpulan secara langsung dari sumbernya serta data sekunder yakni data yang diperoleh dari berbagai catatan, dokumen serta sumber informasi lainnya baik tercetak, elektronik maupun dari internet. Untuk perolehan data 
tersebut dilakukan melalui observasi, wawancara, angket maupun melalui kajian literatur. Sedangkan untuk teknik analisis data dilakukan melalui beberapa tahapan yaitu tahap orientasi lapangan, tahap reduksi data, tahap penyajian da serta tahap verikasi data. Selain itu juga untuk mengetahui tingkat keberhasilan penelitian, peneliti merumuskan beberapa indikator yang mengacu pada empat (4) aspek seperti aspek fungsional, aspek psikologi pengguna, aspek estetika serta aspek keamanan bahan pustaka.

Penelitian ini berlokasi di Pesantren Riyadul Falah yang berada di Kp Pasanggrahan RT 08 RW 03, Desa Pusparaja, Kecamatan Cigalontang, Kabupaten Tasikmalaya. Alasan saya memilih lokasi penelitian di tempat ini dikarenakan di Pesantren Riyadul Falah membutuhkan tata ruang perpustakaan.

\section{Hasil Penelitian Dan Pembahasan Hasil Penelitian}

Sebagaimana yang telah dikemukakan di atas, penelitian ini bertujuan untuk melakukan rancang bangun tata ruang perpustakan di Pondok pesantren Riyadul Falah Kabupaten Tasikmalaya Provinsi Jawa Barat. Dalam penataan tata ruang ini dengan mempertimbangkan empat (4) aspek yakni aspek fungsional, aspek psikologi pengguna, aspek estetika, dan aspek keamanan bahan pustaka.

Dalam melakukan penelitian ini diawali dengan melakukan pra penelitian. Adapun dari hasil orientasi lapangan yang peneliti lakukan diperoleh gambaran bahwa ruangan perpustakaan belum tertata dengan baik ditinjau dari aspek fungsional, psikologis, esteteika maupun dari aspek keamanan koleksinya. Oleh karena demikian dari hasil orientasi lapangan serta hasil wawancara dengan pihak pengasuh pondok pesantren serta para guru, peneliti perlu melakukan penataan ruangan, sehingga ruangan perpustakaan pondok pesantren Riyadul Falah dapat dimanfaatkan para siswa sebagai sumber belajar dan keberadaan mampu menunjang proses belajar mengajar.

Dalam melakukan kegiatan penelitian tindakan (action riset) ini ada empat tahapan yang dilakukan yang meliputi dua (2) siklus penelitian. Adapun tahapannya yaitu tahap perencanaan, tahap pelaksanaan, tahap observasi serta tahap evaluasi atau refleksi. 
Sedangkan untuk rancang bangun tata ruang perpustakaan ini ada empat aspek yang dilakukan yakni sebagai berikut :

Tabel 1 Aspek- aspek Dalam Tata Ruang Perpustakaan

\begin{tabular}{|c|l|l|}
\hline \multirow{4}{*}{$\begin{array}{c}\text { Aspek-Aspek } \\
\text { Tata Ruang }\end{array}$} & Aspek Fungsional & $\begin{array}{l}\text { Peralatan } \\
\text { Elemen-elemen } \\
\text { Ruang }\end{array}$ \\
\cline { 2 - 3 } & Aspek Psikologi Pengguna & $\begin{array}{l}\text { Tata Letak } \\
\text { Pencahayaan }\end{array}$ \\
\cline { 2 - 3 } & Aspek Estetika & $\begin{array}{l}\text { Dekorasi } \\
\text { Warna }\end{array}$ \\
\cline { 2 - 3 } & $\begin{array}{l}\text { Aspek Keamanan Bahan } \\
\text { Pustaka }\end{array}$ & $\begin{array}{l}\text { Sirkulasi Udara } \\
\text { Sistem Keamanan }\end{array}$ \\
\hline
\end{tabular}

Sumber : Darmono, $2007^{8}$.

Berdasarkan hasil pelaksanaan penelitian yang dilakukan pada siklus yang ke I, maka untuk mengukur tingkat keberhasilan penelitian ini dilakukan penyebaran angket pada para siswa. Dari hasil penyebaran angket ini masih ditemukakan beberapa kekurangan. Untuk selanjutnya kekurangan yang terdapat dalam siklus ke-I ini diperbaiki dan disempurnakan lagi pada setiap tahapannya pada siklus ke-Il.

Untuk menghitung keberhasilan dalam penelitian ini, peneliti menyebarkan angkat dengan pertanyaan yang menyangkut 4 aspek penelitian. Angket yang digunakan adalah model tertutup dengan bentuk pilihan ganda yaitu meminta jawaban dan memilih jawaban sesuai dengan pilihan mereka. Skala yang digunakan adalah skala Gutman. Mengenai Skala Gutman menurut Sugiyono ${ }^{9}$ diguanakan untuk mendapatkan jawaban tegas terhadap suatu permasalahn yang ditanyakan. Peneliti memilih skala Guttman karena dengan memilih skala ini akan mendapatkan jawaban yang tegas dan tidak mendua (setuju atau tidak setuju) sehingga peneliti dapat dengan

\footnotetext{
8 Darmono, Perpustakaan sekolah, 234.

9 Sugiyono. Metode Penelitian Kuantitatif, Kualitatif dan R\&D, (Bandung : Alfabeta), 140
} 
mudah menganalisi dan menghitung tanggapan pengguna tentang tata ruang perpustakaan di pesantren Riyadul Falah. Responden dalam penelitian ini berjumlah 42 orang yaitu guru dan siswa.

Untuk menghitung persentasi dalam penelitian ini peneliti menngunakan rumus sebagai berikut :

$$
\begin{aligned}
& \text { Keterangan : } \mathrm{P}=\frac{f}{n} \times 100 \% \\
& \mathrm{P}: \text { Persentase } \\
& \mathrm{F}: \text { Frekuensi (banyaknya jawaban yang keluar) } \\
& \mathrm{n} \text { : Jumlah responden }
\end{aligned}
$$

\begin{tabular}{|c|c|c|c|c|c|}
\hline No & $\begin{array}{c}\text { Fokus } \\
\text { Penelitian }\end{array}$ & Pernyataan & $\begin{array}{c}\text { Pra } \\
\text { Siklus }\end{array}$ & Siklus I & Siklus II \\
\hline \multirow{5}{*}{1} & \multirow{5}{*}{$\begin{array}{l}\text { Aspek } \\
\text { Fungsional }\end{array}$} & $\begin{array}{l}\text { Setuju lokasi ruang perpustakaan } \\
\text { berada dipinggir ruang kelas dan } \\
\text { di depan ruang guru MTs dan } \\
\text { SMK Pesantren Riyadul Falah }\end{array}$ & ada & $100 \%$ & $100 \%$ \\
\hline & & $\begin{array}{l}\text { Setuju ruang perpustakaan terdiri } \\
\text { dari rak koleksi pustaka, meja } \\
\text { sirkulasi dan meja membaca }\end{array}$ & $\begin{array}{l}\text { Belum } \\
\text { Ada }\end{array}$ & $99 \%$ & $99 \%$ \\
\hline & & $\begin{array}{l}\text { Setuju peralatan yang digunakan } \\
\text { di ruang perpustakaan adalah } \\
\text { kayu }\end{array}$ & Ada & $93 \%$ & $93 \%$ \\
\hline & & $\begin{array}{l}\text { Setuju jendela yang digunakan di } \\
\text { ruang perpustakaan } \\
\text { menggunakan jendela yang tidak } \\
\text { berventilasi }\end{array}$ & Ada & $26 \%$ & $100 \%$ \\
\hline & & $\begin{array}{l}\text { Setuju jendela yang digunakan di } \\
\text { ruang perpustakaan } \\
\text { menggunakan jendela yang tidak } \\
\text { berventilasi dan menggunakan } \\
\text { kipas angin }\end{array}$ & $\begin{array}{l}\text { Belum } \\
\text { ada }\end{array}$ & $\begin{array}{l}\text { Belum } \\
\text { ada }\end{array}$ & $100 \%$ \\
\hline \multirow[t]{2}{*}{2} & \multirow[t]{2}{*}{$\begin{array}{l}\text { Aspek } \\
\text { Psikologi } \\
\text { Pengguna }\end{array}$} & $\begin{array}{l}\text { Setuju rak koleksi pustaka, meja } \\
\text { sirkulasi dan meja membaca di } \\
\text { satu ruangan }\end{array}$ & $\begin{array}{l}\text { Belum } \\
\text { ada }\end{array}$ & $86 \%$ & $86 \%$ \\
\hline & & Setuju tata letak ruangan & Belum & $95 \%$ & $95 \%$ \\
\hline
\end{tabular}

Berdasarkan hasil evaluasi yang dilakukan pada setiap siklus, maka dapat dikemukakan hasil sebagai berikut :

Tabel 2 Perbandingan antar siklus 


\begin{tabular}{|c|c|c|c|c|c|}
\hline & & perpustakaan berbentuk persegi & ada & & \\
\hline & & $\begin{array}{l}\text { Setuju tata letak rak koleksi } \\
\text { pustaka dengan meja membaca } \\
\text { berhadapan }\end{array}$ & $\begin{array}{l}\text { Belum } \\
\text { ada }\end{array}$ & $99 \%$ & $99 \%$ \\
\hline & & $\begin{array}{l}\text { Setuju pencahayaan ruang } \\
\text { perpustakaan menggunakan } \\
\text { cahaya alami dari luar }\end{array}$ & Ada & $95 \%$ & $95 \%$ \\
\hline & & $\begin{array}{l}\text { Setuju tata letak penyimpanan } \\
\text { rak buku perpustakaan dibuat } \\
\text { berbentuk } U\end{array}$ & $\begin{array}{l}\text { Belum } \\
\text { ada }\end{array}$ & $67 \%$ & - \\
\hline & & $\begin{array}{l}\text { Setuju tata letak penyimpanan } \\
\text { rak buku perpustakaan dibuat } \\
\text { berbentuk } L\end{array}$ & $\begin{array}{l}\text { Belum } \\
\text { ada }\end{array}$ & $\begin{array}{l}\text { Belum } \\
\text { ada }\end{array}$ & $93 \%$ \\
\hline & & $\begin{array}{l}\text { Setuju warna dinding ruangan } \\
\text { menggunakan warna Aeris } \\
\text { Orange dengan Paradise Green }\end{array}$ & $\begin{array}{l}\text { Belum } \\
\text { ada }\end{array}$ & $93 \%$ & $93 \%$ \\
\hline 3 & Aspek & $\begin{array}{l}\text { Setuju warna furniture rak buku, } \\
\text { meja sirkulasi dan meja membaca } \\
\text { menggunakan warna cokelat }\end{array}$ & Ada & $90 \%$ & $90 \%$ \\
\hline & & $\begin{array}{l}\text { Setuju warna furniture jendela } \\
\text { menggunakan warna hijau tua }\end{array}$ & Ada & $90 \%$ & $90 \%$ \\
\hline & & $\begin{array}{l}\text { Setuju dekorasi yang digunakan } \\
\text { di ruang perpustakaan yaitu } \\
\text { kaligrafi }\end{array}$ & $\begin{array}{l}\text { Belum } \\
\text { ada }\end{array}$ & $95 \%$ & $95 \%$ \\
\hline 4 & $\begin{array}{l}\text { Aspek } \\
\text { Keamanan } \\
\text { Bahan } \\
\text { Pustaka }\end{array}$ & $\begin{array}{l}\text { Setuju sirkulasi udara yang masuk } \\
\text { yaitu udara alami dari luar }\end{array}$ & Ada & $99 \%$ & $99 \%$ \\
\hline
\end{tabular}

Dalam melakukan evaluasi keberhasilan penelitian ini, selain menanyakan ke-empat aspek tersebut, peneliti juga melihat perubahan dalam kunjungan siswa ke perpustakaan. Dari hasil penataan ruangan ternyata secara signifikan dapat meningkatkan kunjungan para siswa pondok pesantren ke perpustakaan. 


\section{Tabel 3 : Statistikk Kunjungan Siswa Ke Perpustakaan}

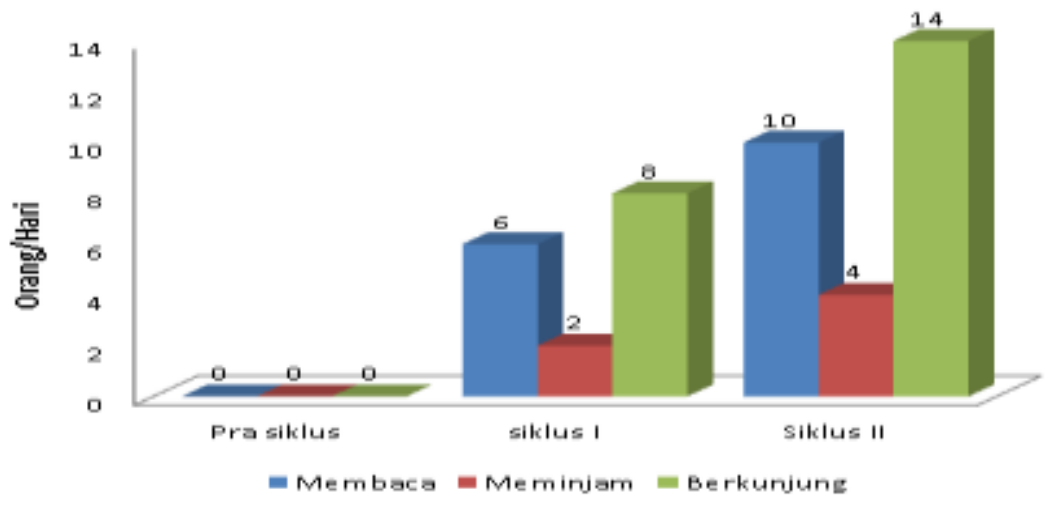

Selain dari hasil penyebaran angket dan wawancara dengan para siwa maupun para pengelola pondok pesantren. Indikator perubahan dari ruangan perpustakaan ini, nampak terlihat dari hasil pengamatan yang peneliti lakukan dari ruang perpustakaan tersebut.

\section{Gambar 1 : Ruangan Perpustakaan Sebelum Dilakukan Penataan}

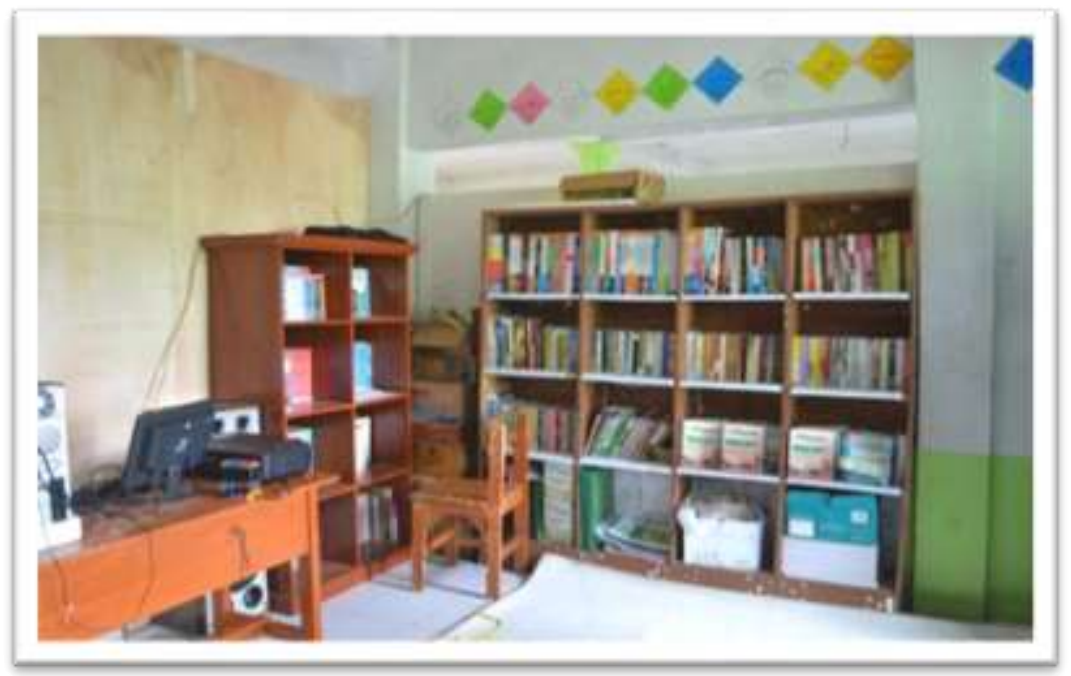




\section{Gambar 2 : Ruangan Setelah dilakukan Penataan}

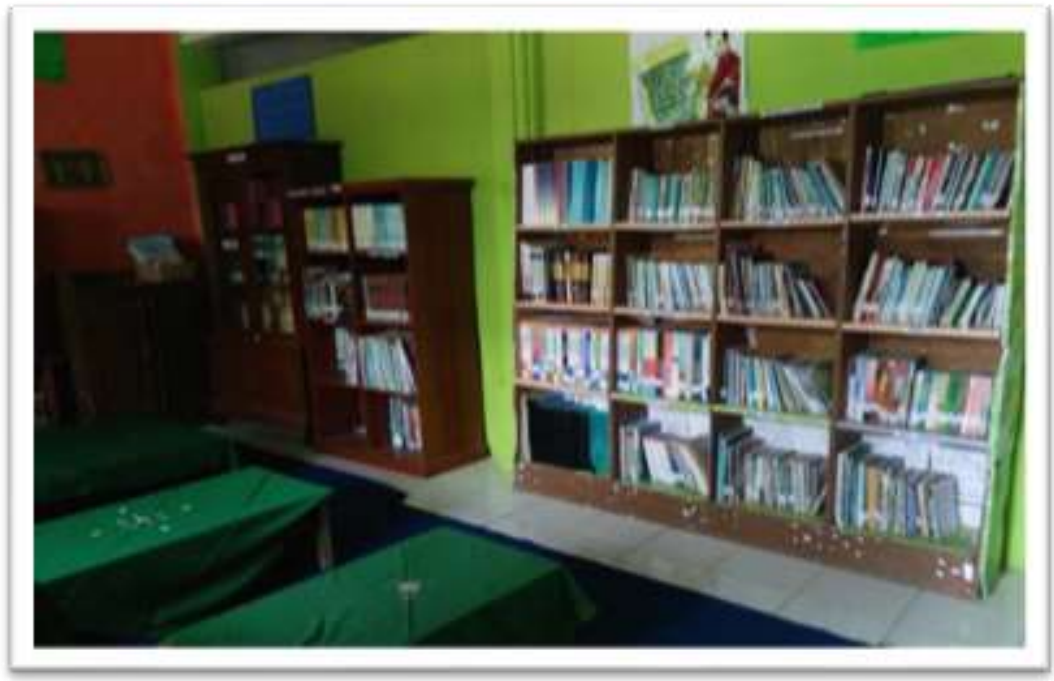

\section{Gambar 3 : Koleksi Setekah Dilakukan Penataan}

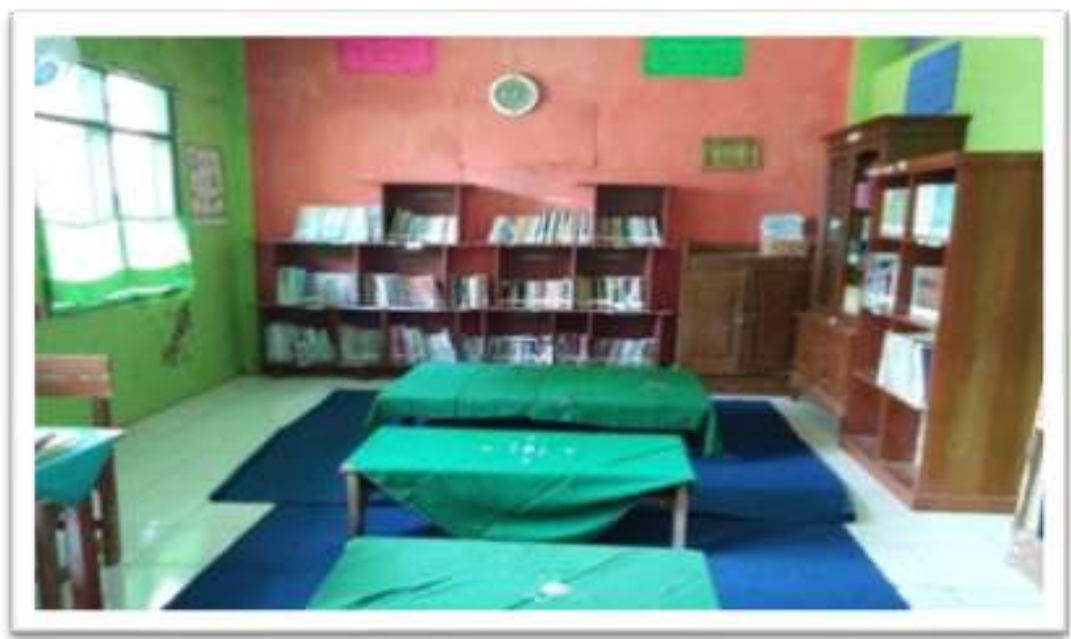

Apabila memperhatikan gambar tersebut di atas, nampak perubahan yang ada dalam ruangan perpustakaan. Setelah dilakukan penataan nampak semakin rapih, koleksinya semakin terata dan tersedia meja untuk membaca dan menulis bagi para siswa dan santri yang datang ke perpustakaan. Oleh karena demikian dengan adanya tata ruang perpustakaan yang lebih baik lagi diharapkan 
perpustakaan dapat dimanfaatkan secara optimal oleh para siswa dan santri sebagai sumber belajar.

\section{Pembahasan}

Rancang bangun tata ruang perpustakaan sebagai pusat sumber belajar di Pesantren Riyadul Falah di lihat dari empat aspek menurut Darmono yaitu aspek fungsional, aspek psikologi pengguna, aspek estetika, dan aspek keamanan bahan pustaka. Luas ruangan yang digunakan ruang perpustakaan menggunakan fasilitas yang ada. Adapun dalam penelitian ini ada empat fokus penelitian yaitu:

\section{1) Aspek fungsional}

Dalam tata ruang perpustakaan di Pesantren Riyadul Falah dilihat dari aspek fungsional yang meliputi peralatan, dan elemen-elemen ruang. Selain peralatan dan elemenelemen ruang, lokasi perpustakaan juga harus di perhatikan. Lokasi ruang perpustakaan Pesantren Riyadul Falah berada di pinggir ruang kelas dan di depan ruang guru MTs dan SMK menjadikan perpustakaan ini sebagai media pusat perpustakaan. Jadi lokasi perpustakaan pesantren Riyadul Falah sudah stategis dan mudah dijangkau oleh siswa.

\section{a. Peralatan}

Untuk peralatan yang di gunakan di perpustakaan meliputi rak buku, meja baca, meja sirkulasi. Peralatan tersebut semuanya terbuat dari kayu. Kayu adalah material standar untuk peralatan. Pertimbangan utama pada bagaimana peralatan tersebut digunakan dan di sambung pada arah urat kayunya. Digunakannya kayu sebagai bahan peralatan karena kayu mampu menerima beban yang searah urat kayunya tetapi dapat penyok jika menerima benturan yang tegak lurus terhadap arah urat kayu tersebut.

b. Elemen-elemen Ruang

Selain peralatan aspek fungsional yaitu elemenelemen yang ada dalam ruangan seperti pintu perpustakaan. Adapun bahan dari pintu tersebut terbuat dari kayu, jendela perpustakaan menggunakan jendela tidak berventilasi. untuk 
mengurangi udara pengap di dalam ruangan serta lantai dan dinding perpustakaan.

\section{2) Aspek psikologi pengguna}

Penataan ruang perpustakaan dapat mempengaruhi aspek psikologis pengguna. Dalam tata ruang perpustakaan meliputi tata letak dan pencahayaan.

a. Tata Letak

Rak buku, meja baca, dan meja sirkulasi. Tata letak rak buku, meja sirkulasi dan meja baca disesuaikan dengan ruangan yang ada. Tata letak ruang perpustakaan berbentuk letter $\mathrm{L}$ dan pengguna merasa nyaman berada di dalam ruangan. Tata letak ruangan disesuaikan dengan luas ruangan yang ada.

b. Pencahayaan

Di perpustakaan pesantren Riyadul Falah menggunakan cahaya alami yang masuk dari luar ruangan. Cahaya masuk lewat jendela yang ada di perpustakaan. Pencahayaan ruangan harus diperhatikan.

\section{3) Aspek Estetika}

Tata ruang perpustakaan harus memperhatikan aspek estetika. Aspek estetika dalam tata ruang perpustakaan Pesantre Riyadul Falah berupa warna dan dekorasi ruangan. Dengan memperhatikan hal tersebut siapa saja yang datang ke perpustakaan dapat merasakan kenyamanan dan akan terlihat indah.

\section{a. Warna}

Warna dinding ruangan perpustakaan menggunakan warna aeris orange dengan paradise green. Warna aeris orange itu orange ini membangkitkan semangat, vitalitas, dan kreativitas. Warna paradise green lebih mirip dengan hijau ini memberikan kesan yang alami menyegarkan dan memberikan efek menenangkan. Warna hijau merupakan warna ciri 
khas dari Pesantren Riyadul Falah. Warna Orange merupakan warna kombinasi.

b. Dekorasi

Kemudian di tambahkannya dekorasi yang di gunakan di ruang perpustakaan seperti kaligrafi dan kata-kata mutiara di tempelkan di dinding Perpustakaan. dengan adanya dekorasi di ruang perpustakaan pengguna merasa nyaman dan ruangan terlihat indah.

\section{4) Aspek Keamanan Bahan Pustaka}

Sistem keamanan bahan pustaka di perpustakaan Riyadul Falah untuk pencegahan kerusakan alami yaitu dengan sirkulasi alami dari luar saja. Selain itu juga untuk pencegahan kerusakan dari ulah manusia pengguna yang akan meminjam buku harus menulis dan melaporkan ke petugas perpustakaan. Adapun megenai sistem keamanan bahan pustakan merupakan hal yang sangat penting. Bahaya pencurian hal ini dapat dihindari dengan cara petugas perpustakaannya harus tegas. Selain itu apabila yang akan meminjam buku harus melapor dan mencatatnya ke petugas perpustakaan.

\section{Kesimpulan dan Saran}

\section{Kesimpulan}

Berdasarkan hasil pengolahan data, maka dapat dikemukakan kesimpulan penelitian sebagai berikut :

1) Rancang Bangun Tata Ruang Perpustakaan Sebagai Pusat Sumber Belajar di Pesantren Riyadul Falah di lihat dari sudut aspek fungsional meliputi lokasi ruang perpustakaan berada di samping ruang kelas, didepan ruang guru MTs dan SMK. Luas ruang perpustakaan berukuran 3,85 $\mathrm{m} \times 5 \mathrm{~m}$. Peralatan yang ada di perpustakaan diantaranya rak buku, meja baca, meja sirkulasi dan kipas angin. Bahan-bahan yang digunakan untuk elemen-elemen ruang perpustakaan terbuat dari kayu, seperti pintu dan jendela. Pintu di perpustakaan menggunakan satu pintu, jendela di ruang perpustakaaan tidak berventilasi. Selain itu lantai ruang perpustakaan menggunakan keramik 
dan di alas dengan karpet, untuk dinding ruangan menggunakan tembok.

2) Rancang Bangun Tata Ruang Perpustakaan Sebagai Pusat Sumber Belajar di Pesantren Riyadul Falah di lihat dari sudut aspek psikologi pengguna yaitu tata letak dan pencahayaan. Untuk tata letak ruang perpustakaan seperti rak buku, meja baca, dan meja sirkulasi di dalam satu ruangan. Meja sirkulasi diletakan didekat pintu masuk. Tata letak diatur berbentuk $\mathrm{L}$ dan disesuaikan dengan ruangan. Selain itu perpustakaan memanfaatkan cahaya yang masuk dari jendela perpustakaan

3) Rancang Bangun Tata Ruang Perpustakaan Sebagai Pusat Sumber Belajar di Pesantren Riyadul Falah di lihat dari sudut aspek estetika meliputi warna dan dekorasi. Warna dinding pada ruang perpustakaan menggunakan warna aeris orange dan paradise green. Warna hijau merupakan warna ciri khas di Pesantren Riyadul Falah. Warna orange merupakan warna kombinasi. Pemilihan warna tersebut memberikan kesan nyaman dan indah pada ruang perpustakaan. Untuk menambah keindahan ruangan perpustakaan maka ditambah dekorasi menggunakan kaligrafi yang ditempelkan pada dinding.

4) Rancang Bangun Tata Ruang Perpustakaan Sebagai Pusat Sumber Belajar di Pesantren Riyadul Falah di lihat dari sudut keamanan bahan pustaka. Untuk mengantisipasi kerusakan alami, ruang perpustakaan memanfaatkan udara alami dari luar. Pencegahan keamanan koleksi pustaka pada pengguna perpustakaan dilakukan dengan cara petugas mencatat identitas pengguna yang akan meminjam buku.

\section{Saran-saran}

1) Pada aspek fungsional di sarankan luas ruangan perpustakaan di perluas agar pengguna merasa leluasa. Kemudian peralatan yang ada di perpustakaan di perlengkap untuk memenuhi kebutuhan pengguna, seperti adanya lemari katalog, rak majalah. Elemen-elemen ruang sebaiknya terbuat dari logam, karena kayu dapat mengundang serangga yang dapat merusak koleksi pustaka. 
2) Pada aspek psikologi pengguna, di sarankan tata letak antara rak buku ada jarak antara rak buku itu dua orang saling memunggungi dan orang bisa lewat, meja baca lebih baik jangan dekat dengan rak buku. Untuk pencahayaan sebaiknya di tambah dengan pemasangan lampu neon untuk menerangi ruangan apabila pada malam hari.

3) Pada aspek estetika dekorasi ruangan di tingkatkan kembali dengan kata-kata yang dapat menyemangati pengguna perpustakaan.

4) Pada aspek keamanan bahan pustaka karena faktor alamiah, di sarankan di dalam ruang perpustakaan menggunakan $A C$ untuk mengatur kelembaban udara.

\section{Daftar Pustaka}

Darmono . Perpustakaan Sekolah : pendekatan Manajemen dan tata kerja. Jakarta: PT. Garsindo, 2007

Peraturan Pemerintah no 19 tahun 2005 tentang Standar Nasional Pendidikan Jakarta: Direktorat Jenderal Pendidikan Dasar dan Menengah.

Rohanda dan Winoto, Yunus. Studi Tentang Pemetaan Budaya

Literasi Masyarakat dan Pengembangan Model Indeks

Membaca Masyarakat Di KBB. (Laporan Hasil Penelitian),

Bandung : FIKOM UNPAD, 2017

Sugiyono. Metode Penelitian Kuantitatif Kualitatif dan R\&D. Bandung: Alfabeta, 2011

Sulistyo, Basuki. Pengantar Ilmu Perpustakaan. Jakarta : PT. Gramedia Pustaka Utama, 1991

Zuriah, Nurul. Penelitian tindakan: Dalam Bidang Pendidikan dan Sosial. Malang: Bayu Media Publishing, 2003 